\title{
Money laundering, tax and the criminal law
}

by Michael Brindle QC

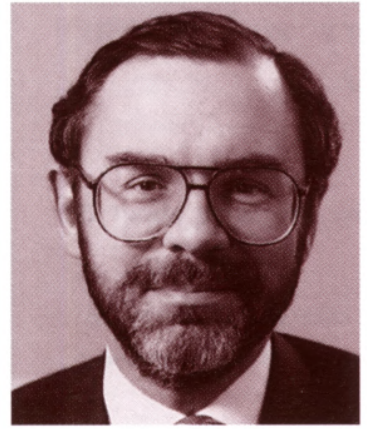

Michael Brindle QC

Michael Brindle QC dicusses the UK statutory provisions relating to money laundering and examines differing views on the scope of their application to the complex areas of tax evasion and foreign fiscal offences.

E veryone has an instinctive concept of money laundering: the handling of the proceeds of crime, its disguise and apparently regular transfer within the banking system. It was for this sort of activity that EC Directive 91/308, OJ 1991 L166/77, came into existence. In the UK, those involved in money laundering can be pursued through the criminal courts; s. $93 \mathrm{~A}, 93 \mathrm{~B}$ and $93 \mathrm{C}$ of the Criminal Justice Act 1988 ('CJA 1988'), enacted through s. 29-31 of the Criminal Justice Act 1993 ('CJA 1993'), provide the necessary legislation.

It is, however, abundantly clear that the UK legislature decided to go significantly further than it was required to do by the EC directive. Article 15 of the directive specifically permits member states to adopt stricter provisions than the directive itself demands, and this is precisely what happened in the UK. There is nothing objectionable about this either in European law or in UK constitutional law, but the results are striking.

The key section is $93 \mathrm{~A}$, which provides as follows:

\section{'Assisting another to retain the benefit of criminal conduct}

93A.-(1) Subject to subsection (3) below, if a person enters into or is otherwise concerned in an arrangement whereby-

(a) the retention of control by or on behalf of another (" $A$ ") of A's proceeds of criminal conduct is facilitated (whether by concealment, removal from the jurisdiction, transfer to nominees or otherwise); or

(b) A's proceeds of criminal conduct-

(i) are used to secure that funds are placed at A's disposal; or

(ii) are used for A's benefit to acquire property by way of investment,

knowing or suspecting that $A$ is a person who is or has been engaged in criminal conduct or has benefited from criminal conduct, he is guilty of an offence.

(2) In this section, references to any person's proceeds of criminal conduct include a reference to any property which in whole or in part directly or indirectly represented in his hands his proceeds of criminal conduct.

(3) Where a person discloses to a constable a suspicion or belief that any funds or investments are derived from or used in connection with criminal conduct or discloses to a constable any matter on which such a suspicion or belief is based-

(a) the disclosure shall not be treated as a breach of any restriction upon the disclosure of information imposed by statute or otherwise; and

(b) if he does any act in contravention of subsection (1) above and the disclosure relates to the arrangement concerned, he does not commit an offence under this section if-

(i) the disclosure is made before he does the act concerned and the act is done with the consent of the constable; or

(ii) the disclosure is made after he does the act, but is made on his initiative and as soon as it is reasonable for him to make it.

(4) In proceedings against a person for an offence under this section, it is a defence to prove-

(a) that he did not know or suspect that the arrangement related to any person's proceeds of criminal conduct; or

(b) that he did not know or suspect that by the arrangement the retention or control by or on behalf of A of any property was facilitated or, as the case may be, that by the arrangement any property was used, as mentioned in subsection (1) above; or

(c) that-

(i) he intended to disclose to a constable such a suspicion, belief or matter as is mentioned in subsection (3) above in relation to the arrangement; but

(ii) there is reasonable excuse for his failure to make disclosure in accordance with subsection (3)(b) above. 
(5) In the case of a person who was in employment at the relevant time, subsections (3) and (4) above shall have effect in relation to disclosures, and intended disclosures, to the appropriate person in accordance with the procedure established by his employer for the making of such disclosures as they have effect in relation to disclosures, and intended disclosures, to a constable.

(6) A person guilty of an offence under this section shall be liable-

(a) on summary conviction, to imprisonment for a term not exceeding six months or a fine not exceeding the statutory maximum or to both; or

(b) on conviction on indictment, to imprisonment for a term not exceeding fourteen years or a fine or to both.

(7) In this Part of this Act "criminal conduct" means conduct which constitutes an offence to which this Part of this Act applies or would constitute such an offence if it had occurred in England and Wales or (as the case may be) Scotland.".'

'(2) In section 102(1) of the Act of 1988 (interpretation of Part VI), the following definition shall be inserted after the definition of "interest"-

" 'proceeds of criminal conduct', in relation to any person who has benefited from the criminal conduct, means that benefit;".

(3) In section 102(2) of the Act of 1988, the following entry shall be inserted in the table after the entry relating to section 71(9)(a)

"Criminal conduct

section 93A(7)”.

\section{GENERAL SCOPE}

This clearly goes well beyond money laundering in the ordinary sense. Subsection (7) extends to all indictable offences, so that those involved in assisting another to retain the benefit of any indictable criminal conduct are liable to prosecution. This includes the proceeds of any offences under the Theft Acts 1968 and 1978, all offences of conspiracy, forgery or counterfeiting, as well as offences which are not essentially financial at all, provided only that they give rise to 'proceeds'.

\section{Concept of 'proceeds'}

An important restriction upon the ambit of the new legislation is the concept of 'proceeds'. A's criminal conduct must have created 'proceeds' which are defined by s. 29(2) of the 1993 Act as follows:

"'Proceeds of criminal conduct", in relation to any person who has benefited from criminal conduct, means that benefit'.

Although this is in a sense a wide definition, there are many crimes which do not give rise to 'proceeds' at all. This is highly relevant to revenue offences, but even in non-fiscal conspiracies the immediate financial benefit may not be easy to determine. Section 71(4) and (5) of the 1988 Act defined 'benefit' to include 'any pecuniary advantage obtained from or in connection with "criminal conduct"', and there seems no reason to give the particular limited definition to 'pecuniary advantage' which is found in s. 16 of the Theft Act 1968 and in the later Theft Act of 1978. Even with this wide definition, however, in order for anybody to be guilty of criminal conduct under s. $93 \mathrm{~A}$, he has to have assisted in the retention of something which can be defined as representing the proceeds of criminal conduct.

\section{Criterion of assistance}

The other principal limitation on the scope of s. $93 \mathrm{~A}$ is the requirement that the person in question should have rendered assistance. There is no whistle-blowing duty imposed by the section. Someone who merely stands by and observes does not commit an offence (although drugs and terrorism are different). The retention of control of the proceeds of criminal conduct must have been 'facilitated'. Concealment is a sufficient form of facilitation, but this clearly requires active participation in the criminal conduct or the laundering of the proceeds thereof. However, the way in which the section is drafted merits attention. Even if the assistance provided is entirely innocent, it comes within s. 93A if the assister knows or suspects that $\mathrm{A}$ is a person who has been engaged in criminal conduct in the past, even if he does not know or suspect that the transaction in question is tainted in any way. Thus, to render innocent assistance to a known or suspected criminal risks liability. In such circumstances it is open to the assister positively to prove, under subsection (4), that he did not know or suspect that the arrangement in question actually related to A's proceeds of criminal conduct, but here the burden is on the assister to disprove what is otherwise a completed criminal offence. The prosecution has done its task in creating the elements of criminal liability by showing:

- the fact of assistance in retention of control; and

- the knowledge or suspicion by the assister that A had in the past been engaged in criminal conduct.

Knowledge and suspicion are obviously broad concepts. Suspicion is sufficient, and, in the case of investment or tax advisers, as well as certain legal advisers, it is possible to take the view that the adviser should be suspicious in almost all circumstances when a large sum of money appears from no very clearly defined source.

How widely, however, will the courts interpret the concept of 'suspicion'? It is likely that they will require more than simply the world-weariness of the experienced professional financial or tax adviser. If the case were to come before the criminal courts, solid evidence would be required on which to ground any suspicion of engagement in criminal conduct. An investment, tax or legal adviser will often have only partial knowledge of a client's affairs, and in such circumstances the court would be keen to ensure that unreasonable and unfair burdens were not imposed upon the professional. Conversely, where a client has delegated the conduct of his financial affairs to such a person, it will be much more difficult for that professional to deny sufficient knowledge of the client's affairs. It will be necessary to see how the law develops, but it is interesting to note that, in the parallel area of civil liability, the Privy Council has made it clear that professionals should only be liable for compensation under the 'knowing assistance' head of constructive trusteeship where dishonesty can be shown (see Royal Brunei Airlines v Tan [1995] 3 ALL ER 97, PC). Clearly, criminal and civil law are different and there is no reason why different results should not be obtained, but it would be somewhat paradoxical if professional advisers could be held guilty of criminal conduct in circumstances where they would not be liable for compensation in a civil court. 


\section{Divergence of opinion among judges}

Even if the parallel with civil liability is adopted, there is some divergence between the opinions of judges as to how dishonesty is to be assessed. In Agip (Africa) Ltd v Jackson [1990] 1 Ch 265, Millett J (as he then was) said the following at p. 294h:

'What did Mr Jackson and Mr Griffin think was going on? There is some evidence of this in the Minutes of the first meeting of the Directors of Keelward Limited of 22 March 1984 and it will be wrong of me to ignore it. This suggests that they thought that their clerk was engaged in evading Tunisian Exchange Control, possibly with the connivance of the plaintiffs and on their behalf - though the Minutes do not say so. In my judgment, however, it is no answer for a man charged with having knowingly assisted in a fraudulent and dishonest scheme to say he thought that it was 'only' a breach of exchange control or 'only' a case of tax evasion. It is not necessary that he should have been aware of the precise nature of the fraud or even of the identity of its victim. A man who consciously assists others by making arrangements which he knows are calculated to conceal what is happening from the third party, takes the risk that they are part of a fraud practised on that party.'

\section{KNOWLEDGE AND SUSPICION}

Knowledge and suspicion are obviously broad concepts. Suspicion is sufficient, and, in the case of investment or tax advisers, as well as certain legal advisers, it is possible to take the view that the adviser should be suspicious in almost all circumstances when a large sum of money appears from no very clearly defined source.

How widely, however, will the courts interpret the concept of 'suspicion'? It is likely that they will require more than simply the world-weariness of the experienced professional financial or tax adviser. If the case were to come before the criminal courts, solid evidence would be required on which to ground any suspicion of engagement in criminal conduct.

A different view was taken by Rimer J in Brinks Ltd v Elcombe (The Times, 23 October 1995) although it does not seem that he was referred to the remarks of Millett J. I have little doubt that the courts, both civil and criminal, would be likely for the most part to follow the views of Millett J. If a professional person knows or suspects that his or her client is involved in some form of dishonest and criminal activity, it is a very uncertain defence to say that he or she did not spot the precise form of dishonest and criminal activity actually being perpetrated.

\section{OFF-SHORE ACTIVITIES}

The most remarkable feature of the new legislation is its extension, through s. $93 \mathrm{~A}(7)$, to the facilitation of criminal conduct taking place outside the UK. It should be noted that Part I of the 1993 Act, which has not yet been brought into effect, seeks to extend the jurisdiction of the UK courts in respect of offences with significant foreign elements. Part III of the 1993 Act deals with money laundering. Section 93A (7) (cited above) reads as follows:

'In this part of this Act "criminal conduct" means conduct which constitutes an offence to which this Part of this Act applies or would constitute such an offence if it had occurred in England and Wales or (as the case may be) Scotland.'
This clearly means that if there were, for instance, a theft in France and an attempt to launder the proceeds of that theft in England, then Part III of the 1993 Act would apply. The potential defendant cannot console himself, when faced with the knowledge or suspicion of criminal conduct, by the reassurance that such conduct is only criminal in a foreign country if, had the conduct occurred in England, it would have been criminal here. This is readily understandable, and an integral part of the process of combating international money laundering.

A problem immediately arises, however. How far must the potential defendant go in acquainting himself with foreign criminal law systems? Interestingly, s. 93A(7) does not enact a 'double criminality' test at all, since (remarkably) it is not necessary that the conduct taking place abroad should actually constitute criminal conduct there, only that it would constitute an indictable offence if it had occurred in England and Wales, or Scotland. Thus, the relevant conduct is notionally transferred from the foreign country to England, Wales or Scotland and treated accordingly, irrespective of the governing foreign law. Thus, it does not seem to be incumbent on a professional investment manager, tax adviser or lawyer to acquaint him or herself with any foreign criminal law at all. Conversely, knowledge of English (or Scottish) criminal law is at a premium since all foreign conduct must notionally be tested according to the English or Scottish criminal law.

How far does this go, however? If ' $\mathrm{X}$ ' and ' $\mathrm{Y}$ ' have conspired in France to rob a German bank, what 'conduct' is it which is notionally transferred to England? Is it simply the conspiracy, hatched in France, to rob the German bank, or is an English bank substituted for the actual German bank? Such questions are not addressed by the legislation. However, in the field of extradition (see below) similar provisions of the Fugitive Offenders Act 1967 have been construed narrowly, so that where conduct in 'Country A' is directed at defrauding persons in 'Country B', only the acts carried out in 'Country A' are notionally treated as having taken place within the jurisdiction of England, as the extraditing jurisdiction ( $R_{v}$ Governor of Pentonville Prison ex parte Osman [1989] 3 ALL ER 701 at 713 F to J). If, however, the conspiracy were hatched in France to rob a French bank, then the same authority would indicate that, at least for the purposes of the law of extradition, both the conspiracy and the fraud would be notionally transferred to England.

\section{TAX}

It is here that the problem arises as to the application of s. 93(A), and the other related sections, to fiscal offences. This has two elements: first, whether the legislation applies to fiscal offences at all and, secondly, how, if at all, it applies to foreign fiscal offences.

Although clearly not specifically envisaged when the legislation was passing through Parliament (see Hansard, 14 April 1993, 859-870) there is nothing in the act which excludes its application to fiscal offences, many of which will fall squarely within the definition that forms the essential framework for the scope of the relevant provisions. It is worth noting that s. 1 of Part I of the 1993 Act, in defining the offences to which Part I when brought into force would apply, specifically includes the common law offence of 'cheating' in relation to the public revenue. This clearly refers to the UK revenue authorities, rather 
than any foreign authorities, but nevertheless provides some support for the idea that the definition of indictable offences in Part III cannot exclude fiscal offences.

The remarks above concerning the concept of 'proceeds' indicate the difficulty in applying the legislation to fiscal offences. For the most part, fiscal crime is not fund-specific - that is to say that the evasion of tax does not normally result in specifically identifiable 'proceeds' which may thereafter be the subject of laundering activities. There may be exceptions to this, for instance in the case of PAYE obligations where an employer is required to make deductions from remuneration before handing it over to an employee: if the sum is paid gross, it is arguable that the excess element paid is the 'proceeds' of a tax evasion. This will not generally be the position. Even the extended definition of proceeds to include any benefit from criminal conduct will still be difficult to apply in the case of most tax evasion. It can hardly be the law that any sums retained by the tax evader, which might have been used to pay his or her taxes, represent the 'proceeds', but, if not, it is difficult to see which particular funds would qualify. This indicates that the legislation was not drafted to take account of fiscal offences, although it is not sufficient argument for excluding tax offences altogether.

\section{FOREIGN TAX}

An acute problem arises as to the application of the legislation to foreign tax evasion. Assume that 'A', a resident Frenchman, has evaded tax due to the French revenue authorities and thereafter approaches an English professional to assist him in investing or otherwise dealing with the 'proceeds'. Leaving aside the difficulty set out above as to the meaning of the term 'proceeds' in this connection, is the English professional concerned at all with any knowledge or suspicion which he might have as to the evasion of foreign tax?

There are two.powerful reasons why he is not concerned with such matters. The first arises out of the construction of s. 93A(7): does one transfer (notionally) from France to England both the activity constituting the tax evasion and also the French revenue authorities themselves, substituting those authorities by the English authorities? If so, would it make any difference if the Frenchman, and his activities within France, had been directed towards defrauding the German tax authorities? Does the translation of the French activity to England bring with it the substitution of the German authorities by the English authorities?

No answer is provided by the 1993 Act. As a matter of statutory construction, it would seem that in neither case would it be legitimate to substitute the English tax authorities for those of either France or Germany. Section 93A(7) refers only to the translation of conduct that has occurred abroad. The occurrence of events is one thing, the replacement of a foreign victim by a notional English victim is another. However there must be some limits to this approach. Simple theft of money in France will necessarily involve a victim, who will probably be a Frenchman. Surely s. 93A(7) cannot be disapplied simply because of the need to substitute an English victim for the French one? If that is right, what is the difference between the ordinary case of theft and the case of tax evasion?

It seems to me that there is a difference. In the case of theft, the identity of the victim is irrelevant to the nature and characteristics of the offence of theft. In the case of tax evasion, however, the particular relationship between the tax evader and his local tax authority may well differ widely between different jurisdictions. In some countries it may be incumbent on a tax payer to volunteer a tax return, giving full and frank information about his financial affairs, whilst in another it may be up to the tax authorities to find the facts and impose a tax charge on the individual. The nature and extent of taxpayers' obligations vary considerably throughout the world, as do the nature and extent of the different taxes which different countries impose on different persons for different reasons. The translation of a foreign tax authority into an English one is not a straightforward matter at all. If the 1993 Act had clearly intended to apply to foreign tax evasion, clearer words than those to be found in s. $93 \mathrm{~A}(7)$ would have been appropriate. For the English criminal court to ignore the particular requirements and characteristics of a foreign revenue authority and simply proceed as if the Inland Revenue were involved, is to overlook the particular characteristics of the foreign revenue authority. Since, as pointed out above, there is no 'double criminality' requirement, such an approach would render the particular characteristics and requirements of the foreign revenue authority irrelevant, and the criminality of the assistance and the retention of the proceeds of criminal conduct would be judged entirely on the basis of an artificial assumption that the foreign revenue authority is to be equated in all respects with the UK Inland Revenue. It is questionable whether the statute is sufficiently clearly defined to achieve this improbable purpose.

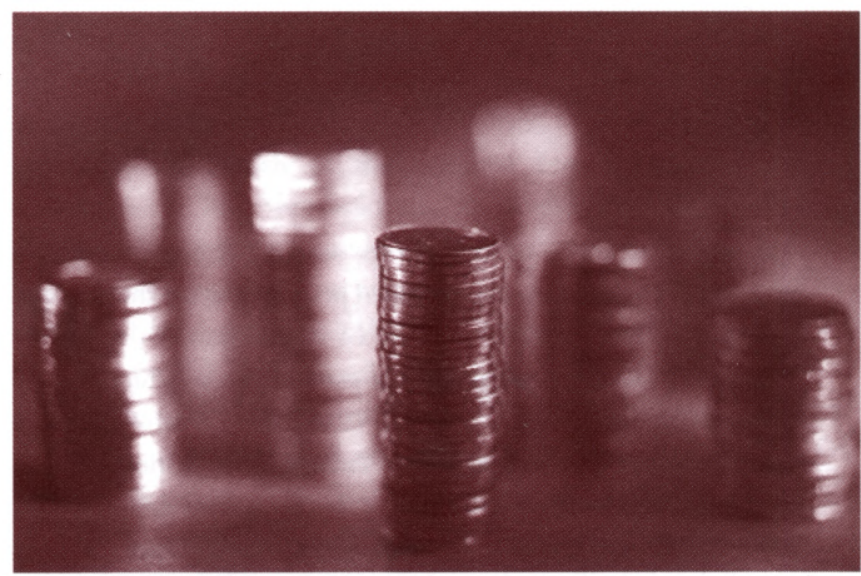

Support is given to these doubts as to the application of the legislation to foreign tax evasion by reference to the established principle of English law, most clearly to be found in the decision of the House of Lords in Government of India v Taylor [1955] AC 491. Claims on behalf of a foreign state to recover taxes due under its fiscal laws are unenforceable in English courts. In relation to civil proceedings it is of ten said that the English courts are not concerned with evasions of foreign revenue law. This is a principle deeply imbedded in English law, as recently re-affirmed by the Court of Appeal in Camdex International Ltd $v$ The Bank of Zambia (No.3) [1997] 6 Bank LR 43. Surely the indictment in England of persons alleged to be guilty of assistance in retention of the proceeds of foreign tax evasion would amount, in reality, to the enforcement of foreign revenue laws, and fall foul of the principle in the Government of India case? Taken together with the points made above as to the meaning of the words used in s. $93 \mathrm{~A}(7)$, there seems to be a powerful case for arguing that the legislation does not apply at all if the only criminal conduct in question is the evasion of foreign revenue law. 
Many cases concerning the evasion of foreign revenue law will also involve other criminal activity, in particular false accounting, and possibly other general criminal offences. Clearly, if false accounting is involved then the fact that the books of account were wrongly written up in a foreign country, rather than in England, will not provide any escape from s. 93A. Nor will it matter at all that the false accounting occurred in the general context of an attempt to evade tax. The interesting case, however, is one of 'pure' tax evasion, where no other offence is committed except the infringement of certain specific foreign revenue legislation. It is reasonably clear that the potential defendant need not be concerned with the precise details of that foreign law, but can he or she be held criminally responsible in England if he or she performs acts of assistance in England in respect of what would have been an offence against the UK Inland Revenue had the act been carried out here? It seems to me that the answer is 'no'. The absence of a double criminality test under s. $93 \mathrm{~A}(7)$ (in contra-distinction to the Money Laundering Regulations 1993) reinforces this conclusion. Where s. $93 \mathrm{~A}(7)$ applies, it does not actually matter whether there is ultimately a foreign tax offence committed at all, provided only that there would have been an offence if the necessary conduct had been committed in England. The absence of any statutory requirement for the conduct committed abroad actually to contravene the law of the country where it occurred can only make sense on the assumption that the requirements and characteristics of criminal conduct in the two jurisdictions are assumed to be effectively the same, as in the simple theft example set out above. It can readily be assumed that all civilised countries will treat theft as criminal conduct, and everyone is assumed to know what, in essence, theft is

\section{Laws of extradition}

Despite the force of the points set out above, there is a formidable counter-argument, based primarily upon the attempt to draw an analogy with the law of extradition. In $R{ }_{v}$ Chief Metropolitan Stipendiary Magistrate ex parte Secretary of State for the Home Department [1988] 1 WLR 1204, the Divisional Court refused to apply the Government of India $v$ Taylor principle to an extradition case, which arose under the Extradition Act 1870. An earlier case, namely $R_{V}$ Governor of Pentonville Prison ex parte Khubchandani [1980] 71 Cr App Rep 241 was not followed in that case, and certain dicta of Stuart-Smith LJ indicate that the Government of India v Taylor principle has no application at all to the criminal law. The case deserves close attention.

As a matter of principle, it is surely obvious that the Government of India v Taylor principle should have no application to the law of extradition. The principle is concerned with the enforcement by the English court of foreign tax law. Extradition is the opposite process, namely the granting of judicial assistance by the English courts to enable foreign courts to try those suspected of criminal conduct in those foreign states. The policy considerations are directly opposite to those which arose in Government of India $v$ Taylor, and which arise in relation to the 1993 Act. With respect to the Court in Khubchandani it is hard to see how it could possibly be a legitimate answer to a valid extradition request to say that the English court, as the extraditing court, cannot and should not enforce foreign revenue law. It seems to me that the court in the second case was plainly right to be unimpressed by the argument based on the Government of India v Taylor principle.
However, it is essential to read the judgment in that case on the basis that it is concerned with extradition, and not with the indictment in England of a person charged with the contravention of foreign tax law.

\section{OFF-SHORE ACTIVITIES}

The most remarkable feature of the new legislation is its extension, through s. $93 \mathrm{~A}(7)$, to the facilitation of criminal conduct taking place outside the UK. It should be noted that Part I of the 1993 Act, which has not yet been brought into effect, seeks to extend the jurisdiction of the UK courts in respect of offences with significant foreign elements.

In 1988, when the case was argued, the 1993 Criminal Justice Act had not even been thought of. The concept of someone being put through the English criminal courts for breach of a foreign tax statute would have seemed to the judges who decided that case to be novel. There was no precedent whatsoever for any such criminal jurisdiction, and therefore the references in the judgment to 'criminal' law were plainly intended as a reference, and only as a reference to the law of extradition itself, which for certain purposes at least is part of the criminal law. Any statement which might be derived from the judgment of Stuart Smith LJ to the effect that the Government of India $v$ Taylor principle does not apply to criminal proceedings can only mean criminal proceedings which are extradition proceedings. Thus, at p. $1218 \mathrm{~B}$, he said:

This is an application of the Rule that our Courts will not enforce foreign penal statutes in the absence of Treaty or specific legislation; but the Extradition Act and the Extradition Treaties are precisely the means by which inroads into that principle are made

and in relation to a passage in Dicey and Morris, 11 th edn, at p. 100 , he continued :

This plainly relates to civil proceedings, since criminal jurisdiction in this country depends upon the crime being committed within the jurisdiction. It is treaty and convention, as given effect to in the Extradition Act, that enable foreign penal laws to be enforced to the extent that they are extradition crimes, and offences under enactment relating to tax are not extradition crimes.

It is clear that the court could not comprehend that criminal jurisdiction (i.e. jurisdiction to try a defendant, and not to extradite him) could arise at all in respect of conduct commitied abroad, let alone the breach of foreign revenue law. Such a possibility being unthinkable, the court was only concerned as to the distinction between civil proceedings and extradition proceedings. If, contrary to the assumption in the judgment, it were possible (as it now is since 1993) for criminal jurisdiction to be founded (extradition apart) in respect of crimes committed abroad, or in respect of assistance given to laundering the proceeds of crimes committed abroad, then there will be every reason to treat such criminal proceedings according to the same principle as applies to civil proceedings, as opposed to the principle applying to extradition proceedings. The general philosophy underlying the application of the principle appears to apply to criminal proceedings of such a nature, which broadly speaking amount to an attempt to enforce foreign revenue laws, 
in clear contrast to the situation which arises on an extradition request by a foreign state, where by definition the English court is not exercising its own jurisdiction to try the defendant, but simply considering returning that person to a 'home' jurisdiction.

In the course of his judgment, Stuart Smith LJ referred to the decision of the House of Lords in Williams and Humbert Ltd $v W$ \& H Trademarks (Jersey) Limited [1986] AC 368, where Lord McKay of Clashfern said at p. 440 that, even in civil proceedings, there were limits on the application of the principle in Government of India $v$ Taylor. However, there the facts were that the plaintiffs were seeking simply to recover property to which they were entitled, even though the Spanish Government lay behind the plaintiff's claim pursuant to certain expropriatory legislation. The plaintiff's claims against the defendants were not in any sense an enforcement of those expropriatory laws, and thus the House of Lords had little difficulty in disapplying any rule of law based upon the principle in Government of India v Taylor. It does not seem to me that the dicta of Lord McKay in that case have any effect upon the issue which is under consideration here.

The arguments based on the analogy with extradition go one stage further. In 1989 English extradition law was radically reformed by the Extradition Act 1989. This introduced the concept of an 'extradition crime', which is dealt with in Section II of the 1989 Act. Extradition crime means :

'(a) Conduct in the territory of a foreign state, a designated Commonwealth country or a colony which, if it occurred in the UK, would constitute an offence punishable with imprisonment for a term of 12 months, or any greater punishment, and which however described in the law of the foreign state, Commonwealth country or colony, is so punishable under that law

It is suggested that there is some similarity between the wording of this section and s. 93A(7) of the 1988 Act (as substituted by the 1993 Act). It has to be said that this similarity is not particularly close, although some similarities certainly exist. For the purposes of extradition, it is sufficient for a crime to constitute an 'extradition crime' if, although committed abroad, it would have constituted a serious punishable offence had it occurred in England. It is suggested that s. 93A(7) should be construed in similar fashion, with the addition of the application of the approach exemplified in the Osman case (referred to above) to the effect that the translation of conduct from the foreign country to England should be accompanied by all the elements of the offence which took place in that country (which in an extradition case would usually mean the requesting state), although perhaps not any other conduct occurring in a third country.

It does not seem to me that this argument has much force. Quite apart from the points made above as to the vital difference between extradition proceedings and true criminal proceedings, there is simply no reason why the two different statutes should be construed in the same way. The concept of the notional transfer of conduct from the requesting state to the extraditing state is a familiar one in extradition law, but a wholly unfamiliar and radical departure for the criminal law proper. It does not seem to me that the English courts should construe a statute conferring original criminal jurisdiction upon the UK courts by reference to any wider than necessary construction, especially if the comparator statute is one which deals with the wholly different topic of extradition.

\section{PARLIAMENT'S INTENTION}

As stated above, little clue can be derived from the parliamentary debate which attended the passing of the original legislation as to its application to foreign fiscal offences. It was only after the change of government in 1997 that any statements came to be made by or on behalf of the UK Government to the effect that this legislation applied to tax-related offences at all. In the Joint Money Laundering Steering Group Guidelines published in June 1997, the statement is made that 'tax related offences are not in a special category'. That seems to be uncontroversial but does not deal with the question of foreign tax offences. The following words also appear:

financial institutions may not be in a position to judge whether a customer has paid tax due in another country. They are not under a duty to investigate.'

Whilst this may be reassuring on the practical level, it appears to suggest that the legislation does indeed apply in principle to foreign tax evasion. The UK government's attitude to tax evasion generally and the role of the remaining British offshore jurisdictions has changed significantly since 1997, and it may be that there is now governmental support for the idea that the 1993 money laundering legislation can and should be applied to those who assist in the retention of the proceeds of foreign tax evasion. Whether or not that is the case, it does not seem that the legislation, when passed, either had that object or was intended to extend so far beyond the ambit of the EC directive.

That there are two schools of thought on this issue cannot be doubted. If the view based upon the analogy with extradition is well founded, it significantly increases the risk that professionals dealing in investment, tax or legal advice here might become embroiled in breach of the criminal law. Because of the comparatively low threshold of 'suspicion', it will be very difficult to be certain in many situations that a particular client has not been engaged in or benefited to some extent from some evasion of foreign tax law. Although it is clearly not incumbent upon the English professional to research the foreign tax law, the application of s. $93 \mathrm{~A}(7)$ to such facts will potentially bring within the ambit of the criminal statute many situations which arise regularly in practice. The problem of identifying the 'proceeds' of such criminal conduct will be one factor in inhibiting prosecutions of this nature, whilst another will obviously be the doubt as to whether the act applies to foreign fiscal offences at all. I am not aware of any fiscal offence case yet where the act has been used. I doubt whether there will be one, at least until and unless the authorities have established a reasonably firm basis for the operation of the act in relation to what might be described as more traditional money laundering activities.

\section{MICHAEL BRINDLE QC}

